\title{
Using of Index Biological Integrity of Phytoplankton (P-IBI) in the Assessment of Water Quality in Don River Section
}

\section{E.N Bakaeva ${ }^{1}$}

\author{
Murooj Abbas Buhlool AL-Ghizzi ${ }^{2}$
}

\section{Zahraa Zahraw Aljanabi ${ }^{3}$}

\author{
${ }^{1}$ Department of Hydrochemical, Institute, Rostov-on-Don, Russia. \\ ${ }^{1}$ Southern Federal University, Institute of Earth Science. \\ ${ }^{1}$ Institute of Water Problems of the Russian Academy of Sciences, Hydrochemical department, Rostov-on- \\ Don ${ }^{2}$ Southern Federal University, Academy of Biology and Biotechnology, Rostov-on-Don, Russia. \\ ${ }^{2}$ Department of biology College of Sciences, University of Thi Qar, Iraq. \\ ${ }^{3}$ Environment Research Center, University of Technology, Baghdad. Iraq. \\ *Corresponding author: rotaria@mail.ru, muroojabas6@gmail.com*, zahraa.z.farhan@uotechnology.edu.iq \\ "ORCID: https://orcid.org/0000-0001-5694-616x, https://orcid.org/0000-0003-3513-073x" , https://orcid.org/0000- \\ $\underline{0002-4891-0930}$
}

Received 8/8/2020, Accepted 22/11/2020, Published Online First 6/12/2020, Published 1/3/2021

This work is licensed under a Creative Commons Attribution 4.0 International License.

\begin{abstract}
:
The multimetric Phytoplankton Index of Biological Integrity (P-IBI) was applied throughout Rostov on Don city (Russia) on 8 Locations in Don River from April - October 2019. The P-IBI is composed from seven metrics: Species Richness Index (SRI), Density of Phytoplankton and total biomass of phytoplankton and Relative Abundance (RA) for blue-green Algae, Green Algae, Bacillariophyceae and Euglenaphyceae Algae. The average P-IBI values fell within the range of (45.09-52.4). Therefore, water throughout the entire study area was characterized by the equally "poor" quality. Negative points of anthropogenic impact detected at the stations are: Above the city of Rostov-on-Don $(1 \mathrm{~km}$, higher duct Aksai) was 38.57 in June, the lower inflow of the Temernik river which was 38.57- 41.42 in summer and below the spillway was $38.57-34.28$ in August. At these stations, samples with P-IBI values more than 56, characterizing water quality as "Fair", were not found in any of the observations. The negative effect on the water at the stations may be due to the influence of the closely located Aksai city and the impact of the Temernik River. In Russia P-IBI have not been used yet, so this study can be considered as the first study that's conducted to assess the environmental status of the Don River by using the phytoplankton index of Biological Integrity and has developed scoring criteria of the Don River (P-IBI) and other watercourses of the south of Russia. The continuous monitoring relaying on the selection of the most suitable metrics score is recommended.
\end{abstract}

Key words: Assessment, Index biological integrity of phytoplankton, Phytoplankton, water quality, Don River, Rostov-on- Don City, Russia.

\section{Introduction:}

Globally, it is very important to assess the degradation and restoration of aquatic ecosystems, especially for freshwaters systems, which are necessary for use in multiple important purposes (1).

The existing methods for the comprehensive assessment of surface water pollution are fundamentally divided into two groups: the first includes methods that allow us to assess water quality by chemical, physical, biological, microbiological methods; the second group used complex indices $(2,3)$. It is clear that a quantitative analysis of any impurity in water alone does not provide an answer to the main question about the danger to biota and need to develop more robust metrics that better represent water quality $(4,5,6)$. Unfortunately, these two critical characteristics do not provide complete information about water quality. An integrated assessment of water quality and its degrees can be obtained by the Biological Integrity Index (IBI). Multimetric indices are widely applied to evaluate the environmental situation of surface water as well as ecosystem management because they are more active than their component metrics (7). Multimetric indices represent different functional and taxonomic collections within the group, which respond 
differently to several pressures and can reflect the ecological status. (8).

Karr and Kane $(9,10)$ stated that solving the problems of water resource would not come from a fine disclosure of chemical materials or the development of methods for determining forms of degradation. The legislation was enacted during 1972 (Amendments to the Water Pollution Control Act-WPCA) and in 1977 (the Clean Water ActCWA) which called for the maintenance and restoration of not only the chemical and physical safety of US waters but as well for the biological safety of these concerned waters (9). Because of the fundamental inclusion criteria of biosafety in this definition, chemical and physical measures of water are no longer sufficient for the evaluation of water quality (10). Frequently IBIs based on fish or benthic invertebrate were mostly used (11).

Consequently, several biological tests of water quality were used later mainly as IBI (index of biological integrity), which can be define as a tool for measuring the water quality of the ecosystem (10).

The Index Biological of Integrity IBI was developed by Karr and utilized to measure the biological safety of water bodies, using the fish index (9). IBI as a multi-scaled approach has become the most widely used to assess ecological condition of river, the P-IBI is an easily, valuable, complementary mathematic tool that's used for assessing aquatic ecosystem health and evaluating restoration projects (12). In Russia P-IBI has not been applied yet.

Phytoplankton responds to change resulting from pollutant inputs for any water system, especially nutrients. Methods of the collection phytoplankton are inexpensive, in addition to that, samples of Phytoplankton can be stored for a long time, and the historical samples can be analyzed and compared to current samples taken in this study (13).

IBI has been applied to multiple aqueous systems for various purposes, in addition, the P-IBI applied in this study efficiently identified the main environmental parameters that are related with each level (bad, low, and moderate) $(12,14,15)$.

In particular, the P-IBI (Phytoplankton Biosafety Index) method is a useful method for reaching critical management decisions and publicizing the health of the ecosystem (12), so the purpose of this research is to assess the state of the Don River using the Phytoplankton index of Biological Integrity and also to develop a scoring criterion for the Don River.

\section{Materials and Methods: \\ Study area}

The Don River is one of the largest rivers in the European part of Russia. Its length is $1870 \mathrm{~km}$, the catchment area is 442 thousand $\mathrm{km}^{2}$, the length of the lower reaches of the river. Don (Lower Don) from the Tsimlyansk reservoir to the Taganrog Bay is $313 \mathrm{~km}$ (16).

The length of the Don River is $313 \mathrm{~km}$ from the Tsimlyansk reservoir to the Taganrog Bay, which is called the Lower Don system. The average water depth at low flow rates from 4 to $6 \mathrm{~m}$ in the main channel and decreases to $0.7 \mathrm{~m}$ in the shallows. The mouth of the Don is located downstream from the city of Rostov-on-Don. The river depletes about 340 $\mathrm{km}^{2}$ (17). The study area included 8 stations on the Don River within Rostov-on-Don (Table 1).

Table 1. The study area included 8 stations on the Don River within Rostov-on-Don

\begin{tabular}{lcc}
\hline Stations name & Distance from riverside, $(\mathrm{m})$ & Deep, $(\mathrm{m})$ \\
\hline St.1. Above the city of Rostov-on-Don $(1 \mathrm{~km}$, higher & - & 0.3 \\
duct Aksai) & - & 0.3 \\
St.2. at the level of new water intake & - & 0.3 \\
St.3. 0.5 lower inflow of the Temernik river & - & 9.0 \\
St.4. 0.5 lower inflow of the Temernik river & & 0.3 \\
0.5 below the spillway: & 0.1 & 0.3 \\
St.5 & 0.5 & 5.0 \\
St.6 & 0.5 & 0.3 \\
St.7 & 0.9 & \\
St.8 & & \\
\hline
\end{tabular}




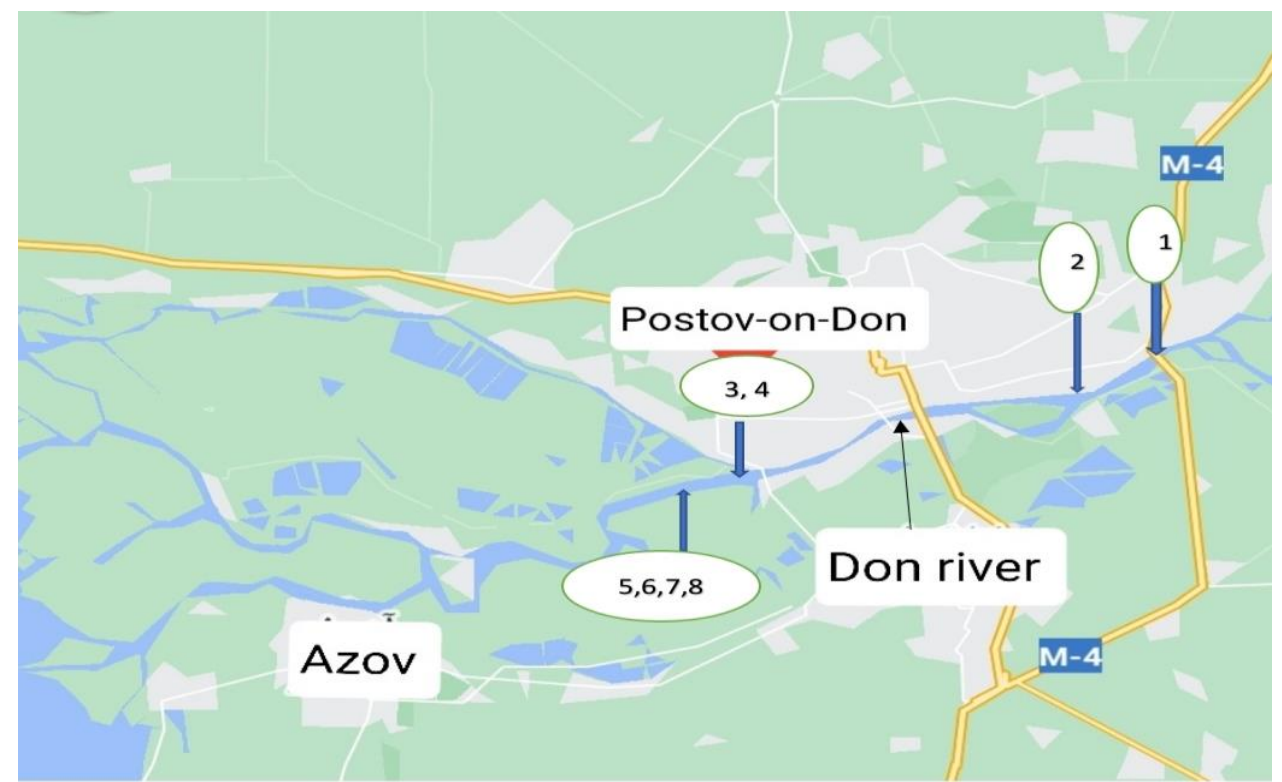

Figure 1. Studied Stations on Don River in Rostov-on-Don city, Russia

\section{Sampling}

Water Samples were collected from April to October 2019 from eight Stations in Don River within Rostov-on-Don city. Samples of phytoplankton were collected from subsurface (30 $\mathrm{cm})$ according to the method recommended by (18) in order to obtain a correct picture of the qualitative and quantitative composition of the phytoplankton species, then preserved with formalin's solution (10 $\mathrm{ml}$ of this preservative is quite sufficient for $500 \mathrm{ml}$ of water sample containing phytoplankton).

The samples of phytoplankton were taken by a net $(20 \mu$ mesh size). The contents of the net were then concentrated and preserved in $2 \%$ formalin solution. Several slides of Phytoplankton from each sample were prepared in order to be identified and counted to determine the community composition of Phytoplankton and the relative ratios of each taxonomic group in the sample. Identification process for species was made by a compound microscope, according to the $(19,20,21,22,23$, 24).

The sum of monthly densities of each species was calculated to obtain the total density of species. Then species were arranged according to proper metrics. The phytoplankton metrics used for P-IBI included: phytoplankton density $\left(\right.$ cell/ $\left./ \mathrm{L}^{3}\right)$, phytoplankton biomass, richness index and the relative abundance (RA) of Bacillariophyceae, Chlorophyceae, Cyanophyceae, Euglenaphyceae.

\section{P-IBI calculation}

Metric raw data were converted into metric scores after being submitted to a scale of thresholds of 3, 5 and 10 (25) (Table 2). The development of these thresholds was carried out according to
$(17,26,27)$ based on the historical data and professional judgment as recommended in EPA (29). Threshold of high score 10 was given for metrics that have values equal or near to reference condition, 5 was given to those of medium or moderate conditions, while 3 was-given to those of worst or unhealthy conditions. Astin (25) refer to these values as a good reflection of trophic status from the traditional measures. The sums of these metric scores for each studied Station were calculated monthly as the P-IBI.

Final index scores were grouped into four rating categories of "Excellent", "Good", "Fair", "Poor" and "Very Poor" as in Table $3(29,30)$. A value of rating categories close to 82 indicates that streams biology is healthy and equivalent to what would be found in a natural system condition, a value close to 56 reflect a poor biological status within the aquatic ecosystem. Table 3 illustrates the cutoff values for the final P-IBI scores and qualitative interpretation $(29,30)$.

The minimal and maximal cutoff values for each class represent the outcome of multiplying the minimal values (i.e., 3) and the maximal values (i.e., 10) scoring criteria. It collected the values of the metric scores and hit in ten then divided by the number of metric scores to ensure that the resulting number does not skip number 100 in any case.

$\mathrm{P}-\mathrm{IBI}=\sum_{j=1}^{S} \frac{1}{M}(E A+C B+R J+L M+R A+$ $Z B) * 10$

(10).

Where,

$\mathrm{M}=$ number of metrics

$\mathrm{EA}=$ Phytoplankton Density metric score.

$\mathrm{CB}=\mathrm{R}$.A. of Cyanophyceae metric score.

$\mathrm{RJ}=\mathrm{R} . \mathrm{A}$. of Bacillariophyceae metric score. 
$\mathrm{LM}=\mathrm{R}$.A. of Chlorophyceae metric score.

$\mathrm{ZB}=$ Richness Index metric score.

$\mathrm{RA}=\mathrm{R} . \mathrm{A}$. of Euglenaphyceae metric score.

Table 2. The Scoring Criteria of Different Sites of the Don River, Russia

\begin{tabular}{lccc}
\hline \multicolumn{1}{c}{ Metrics } & \multicolumn{3}{c}{ Scoring Criteria } \\
Phytoplankton Density & $\mathbf{3}$ & $\mathbf{5}$ & $\mathbf{1 0}$ \\
Phytoplankton Biomass & $>16098$ & $369.9-16098$ & $<369.9$ \\
R.A. of Cyanophyceae & $>24.4983$ & $0.4214-24.4983$ & $<0.4214$ \\
R.A. of Bacillariophyceae & $>24.4983$ & $0.4214-24.4983$ & $<0.4214$ \\
R.A. of Chlorophyceae & $<47.7$ & $47.7-95.3 \%$ & $>95.3 \%$ \\
R.A. of Euglenaphyceae & $<2.8 \%$ & $2.8-26.91 \%$ & $>26.91 \%$ \\
Richness Index & $>7.7 \%$ & $0.3-7.7 \%$ & $<0.3 \%$ \\
\end{tabular}

Table 3. Cutoff Values of IBI Scores $(29,30)$

\begin{tabular}{cc}
\hline Ecosystem Condition & Metric IBI Score \\
\hline Excellent & $<82$ \\
Good & $72-82$ \\
Fair & $56-72$ \\
Poor & $>56$ \\
\hline
\end{tabular}

\section{Results and Discussion:}

Four main maxima in the total cell number can be distinguished at stations $1,4,7,8$ occurring in July and the second during June in stations 1,8 (Fig. 2). The seasonal variations in phytoplankton population may occur due to the changes in the environmental factors through the study period (31). Higher total cell counts may be attributed to the high nutrient values received as domestic disposal that discharge in these stations (32).

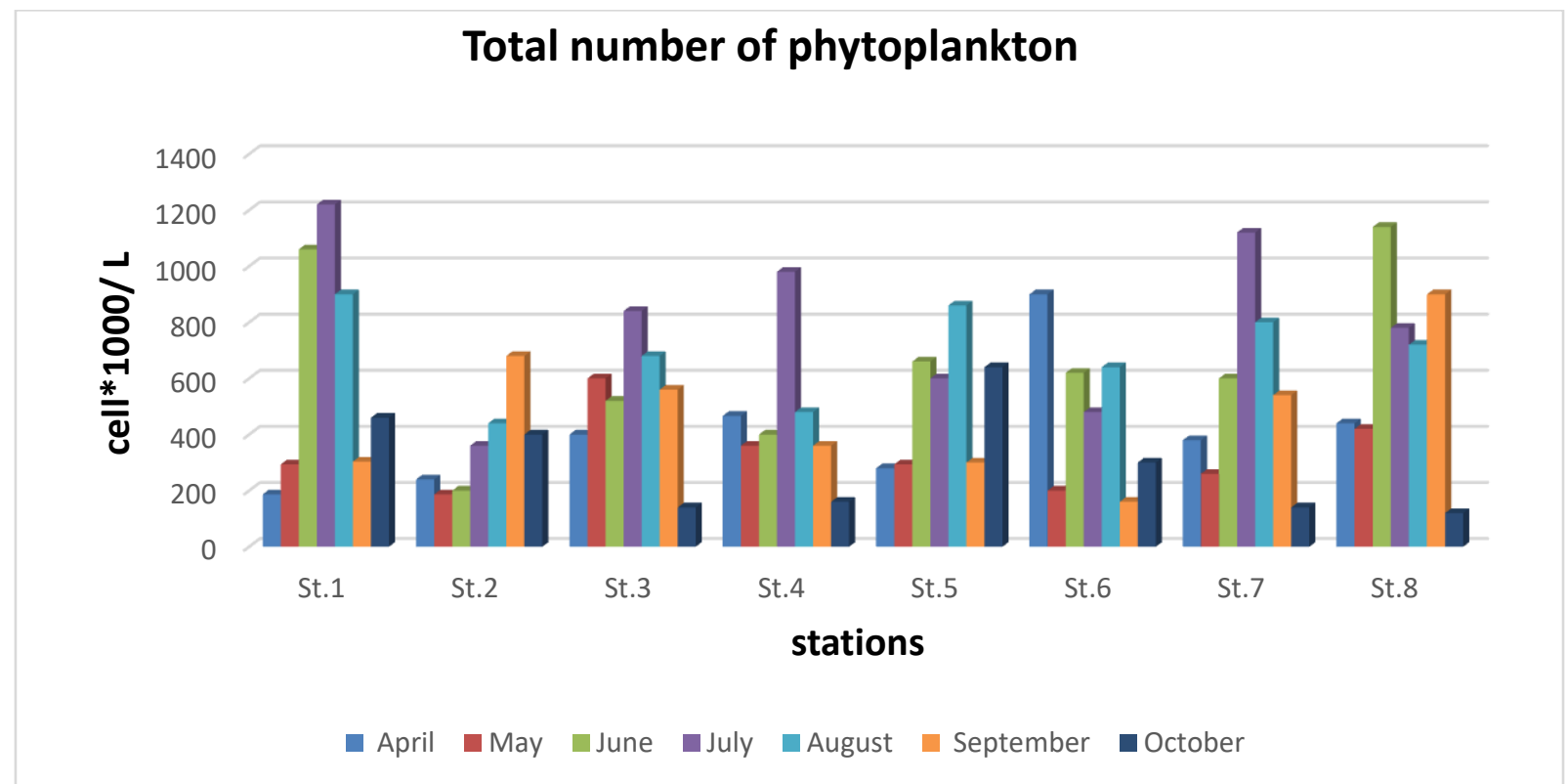

Figure 2. Monthly variation of the total number of phytoplankton $\left(\mathrm{Cell}^{*} 10^{3} / \mathrm{L}\right)$ for all stations.

Two principal maxima in the total biomass can be distinguished at stations 4,7 occurring in July and the second during June in stations 7, 8 (Fig. 3). Abundance for the phytoplankton counts is given where it is available, knowing better information about the productivity of an area than presence data without it. The lower abundance may manifest a low level of production, but this status may not be the case if these are large cells. The data of biomass helps to exhibit the productivity of any area of interest. The biological volume has been calculated for each cell count and when getting to biomass, is available for utilize to assist in the interpretation process of an area's productivity (13). 


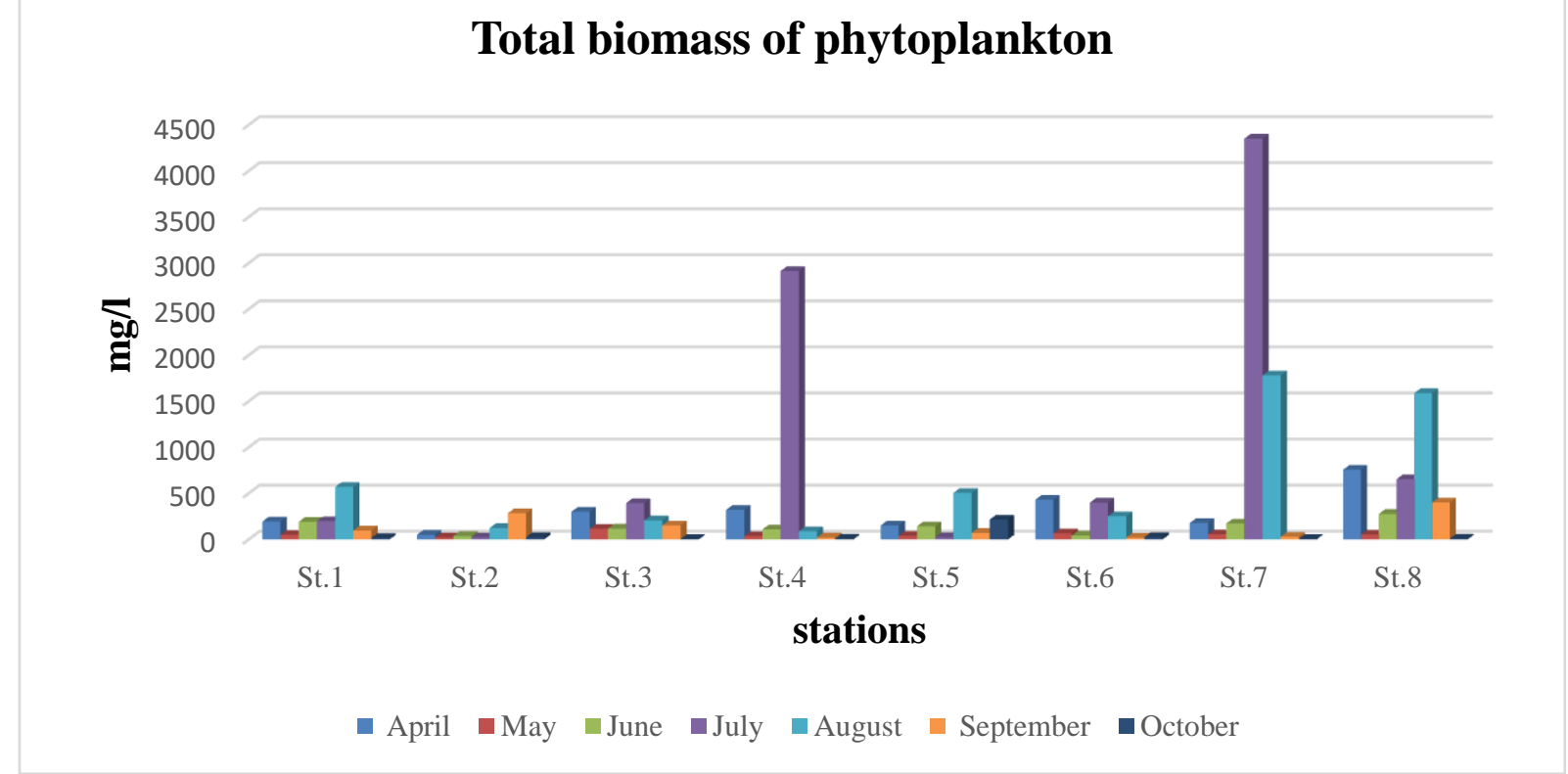

Figure 3. Monthly variation of the total biomass of phytoplankton (mg/l) for all stations.

The result showed that monthly variations occurred between months and in some species of phytoplankton, the relative abundance of Bacillariophyceae was higher in all stations in
April, in station 2 in June and May in stations 6,7, 8 (Fig. 4). This may be referred to the deterioration of water quality in the study area.

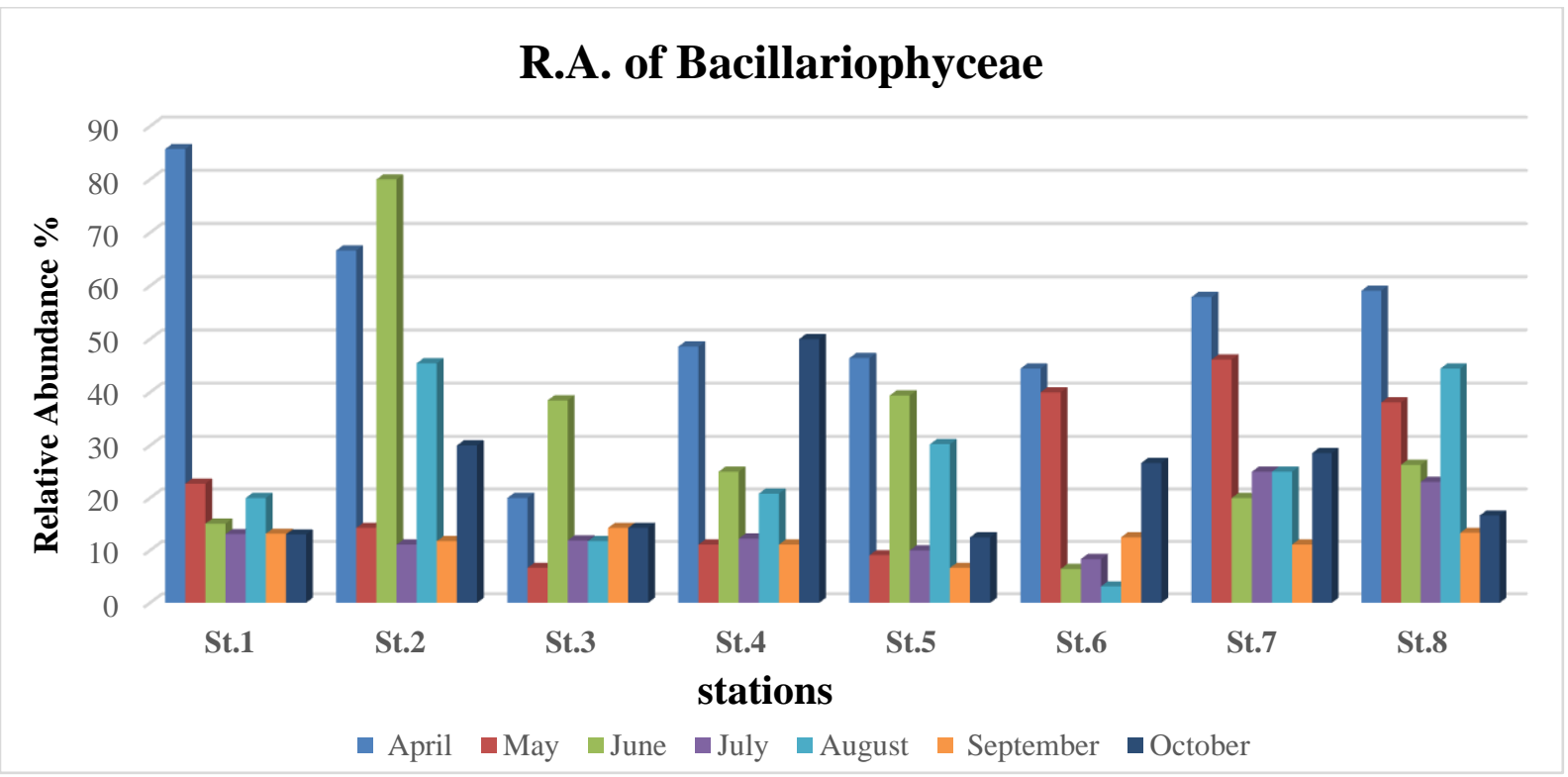

Figure 4. Monthly variation of the Relative Abundance (\%) of Bacillariophyceae for all stations.

Cyanophyceae were the second most important group. This group is the most abundant flora in July, August, September and October in almost all stations (Fig. 5). In July, August, September diatom is replaced by blue-green algae because the suitable conditions (such as; light, temperature, and relatively high nutrient availability) that's led to increasing the density (mainly cyanobacteria) (34). In October, the species composition becomes poor while maintaining intensive vegetation of the bluegreen algae Rhabdoderma lineare, Rhabdoderma sigmoideaand Aphanothece sp, and the flowering intensity is often greater than in summer. It is clear that such significant fluctuations indicate an unstable state of the biocenosis (12). The indicator significance of species, allows to conclude that the level of assessment, according to P-IBI generally corresponds to flowering intensity waters. 


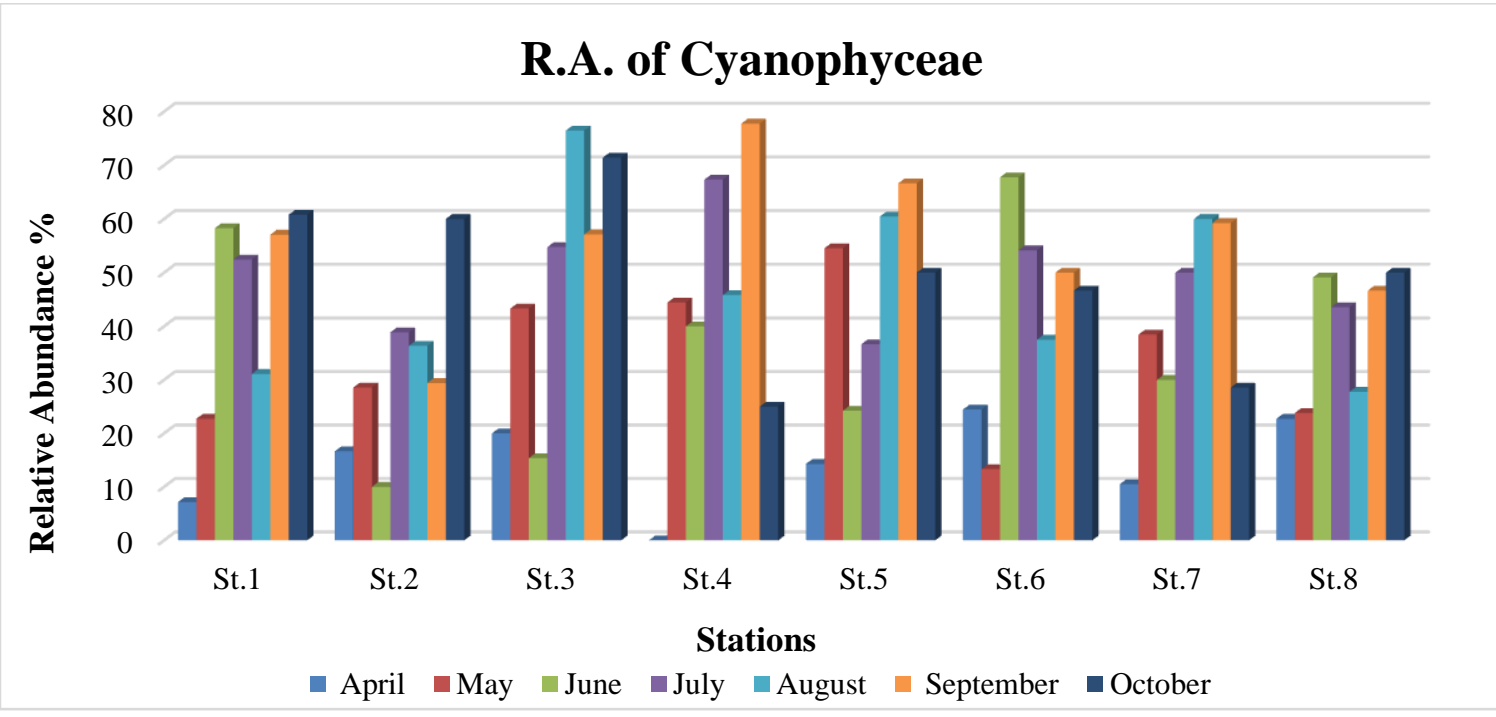

Figure 5. Monthly variation of the relative abundance (\%) of Cyanophyceae for all stations.

Chlorophyceae were the third most important group. They contributed in a large number of species but lower cells numbers compared with Bacillariophyceae. This group is the most abundant flora only in June and July in stations 2 and 5 respectively, and there are no significant differences in abundance between most stations and other months (Fig. 6), which may be due to their preference for moderate conditions. Other factors may include higher efficiency of light absorption and nutrient uptake (33).

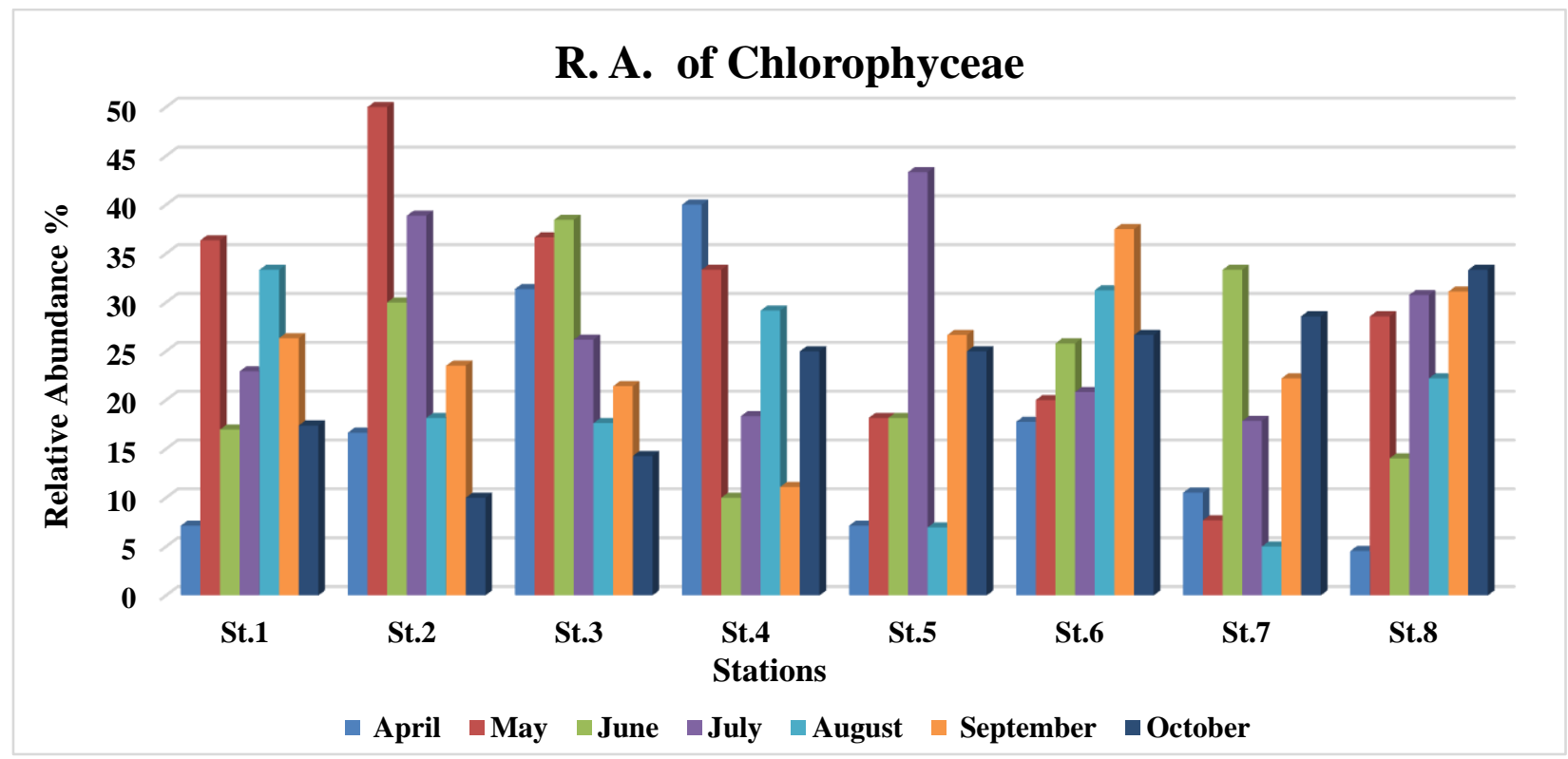

Figure 6. Monthly variation of the relative abundance (\%) of Chlorophyceae for all stations.

Class of Euglenophyceae was abundant with minor numerical importance (Fig. 7). The overall results of this study indicate that in stations
4,5,6 in September and in stations $2,3,4,6,8$ in October have phytoplankton indicative of perhaps some indication of organic pollution near the cities. 


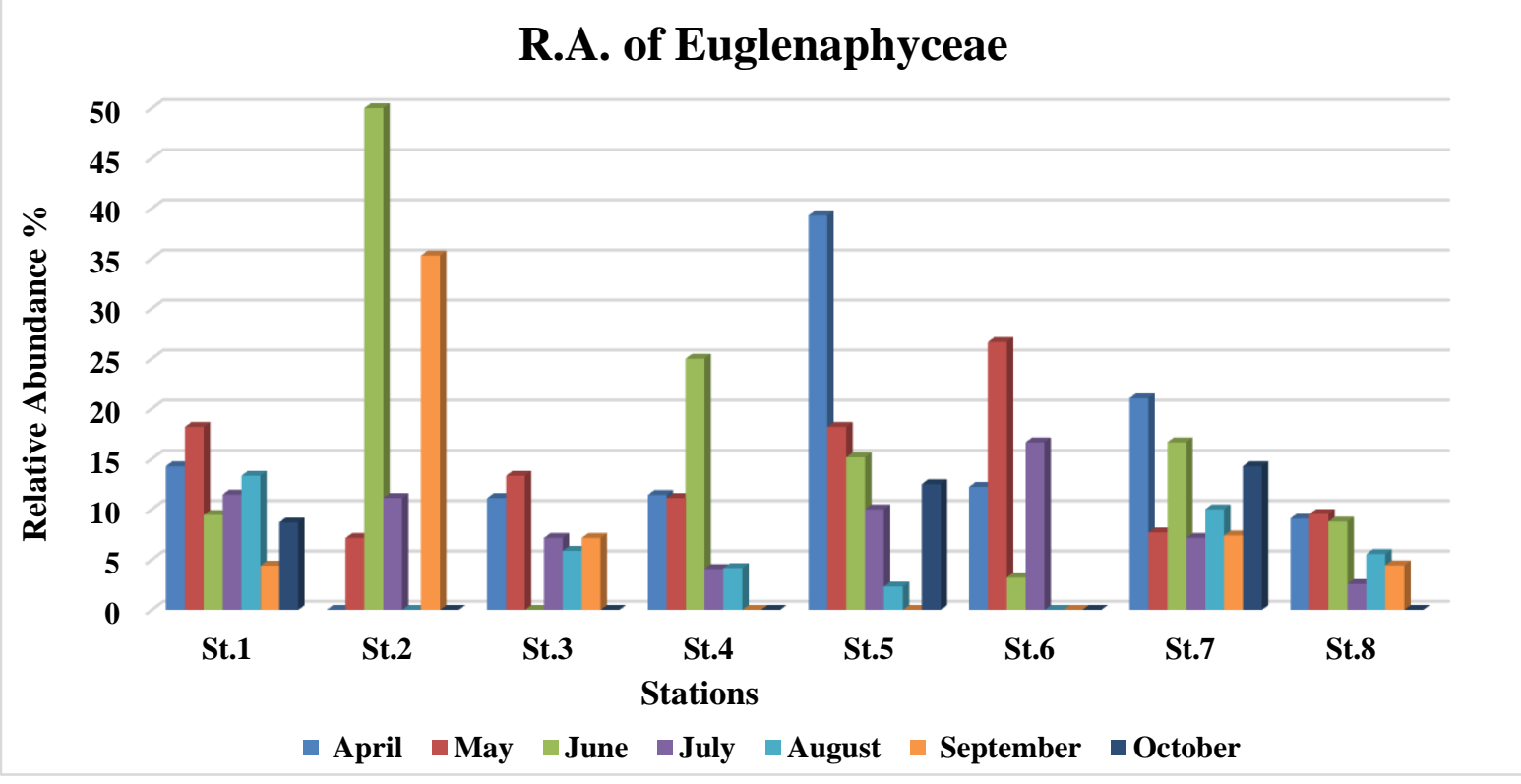

Figure 7. Monthly variation of the relative abundance $(\%)$ of Euglenophyceae for all stations.

Higher values of species richness index were recorded during April in station 6 and station 1 in July Fig. 8). In the station 1 species richness was relatively high in all months, which indicates good environmental conditions conducive to the development of many species' moderate trophy of waters (34). It was only in May in station 6 samples have lower values which was reflected by the lowest recorded number of species as well as by the domination of single species, accompanied by low proportions of other taxa (35).

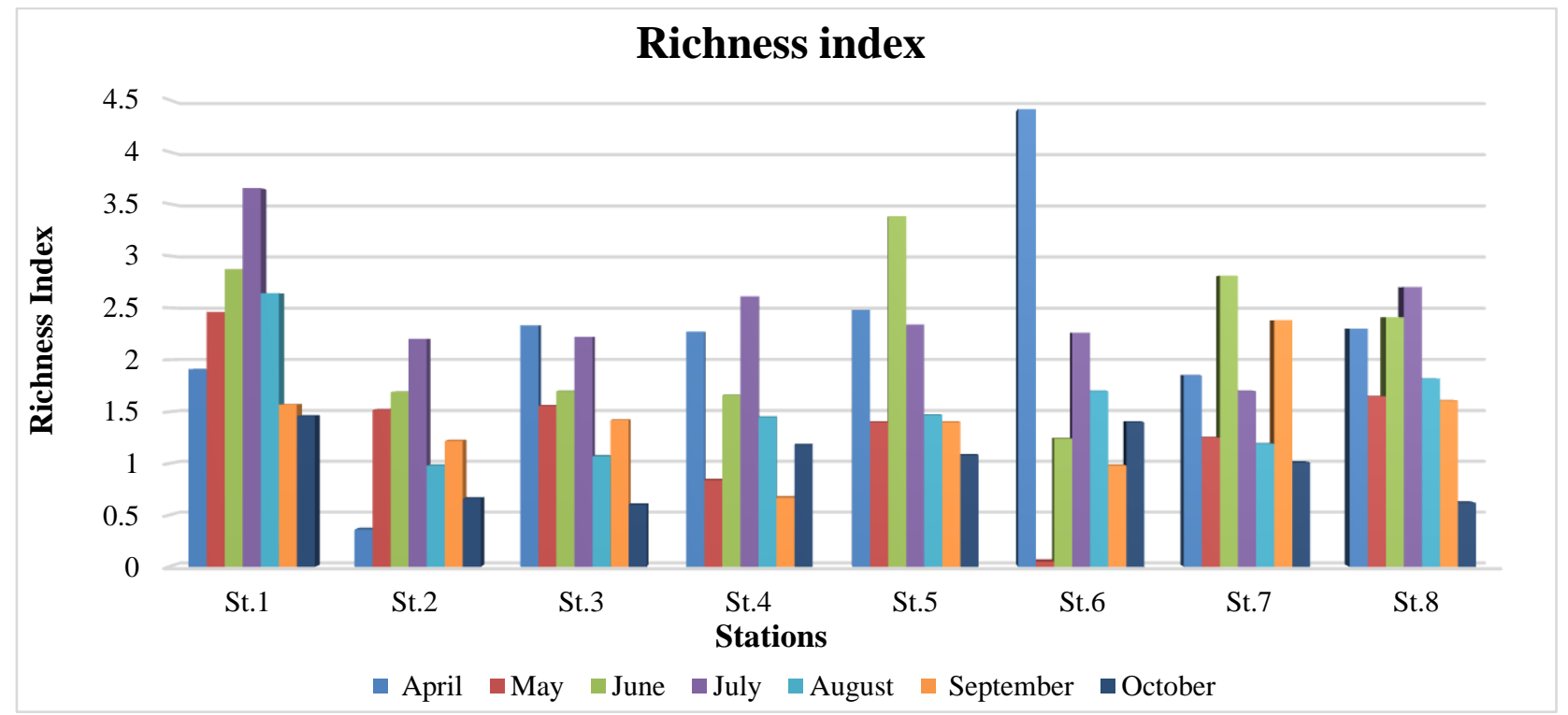

Figure 8. Monthly variation of the Richness Index for all stations.

P-IBI results ranged between 34.28 - 64.28 "Poor to Fair" ecosystem conditions (Fig. 9). The higher score of P-IBI recorded in this study was 64.28 found in station 4 during October, and the lowest value 34.28 found in station 8 during August. This manner coordinated with much research done on Don river to demonstrate that the development of alga is characterized by significant intra-annual fluctuations in the number of algae and the heterogeneity of the spatial distribution. In autumn, the species composition becomes poor while maintaining intensive vegetation of the bluegreen Microsystis aeruginosa and Aphanizomenon fos-aqua, and the flowering intensity is often higher than in summer. It is clear that such significant fluctuations indicate an unstable state of the biocenosis (36).

The blooming of phytoplankton community in spring, where the increasing of their variety and numbers follows the increasing in; ideal 
photoperiod, nutrients conditions, temperature and hydrodynamic forces of surface water like mixing and stratification, etc. All these factors eventually support good growth situation of the individuals (33). Otherwise, the decline of P-IBI values during autumn refers to degreasing in the concentration of the parameter that's are important or vital to whole phytoplankton communities which in turn reflected on the P-IBI score.

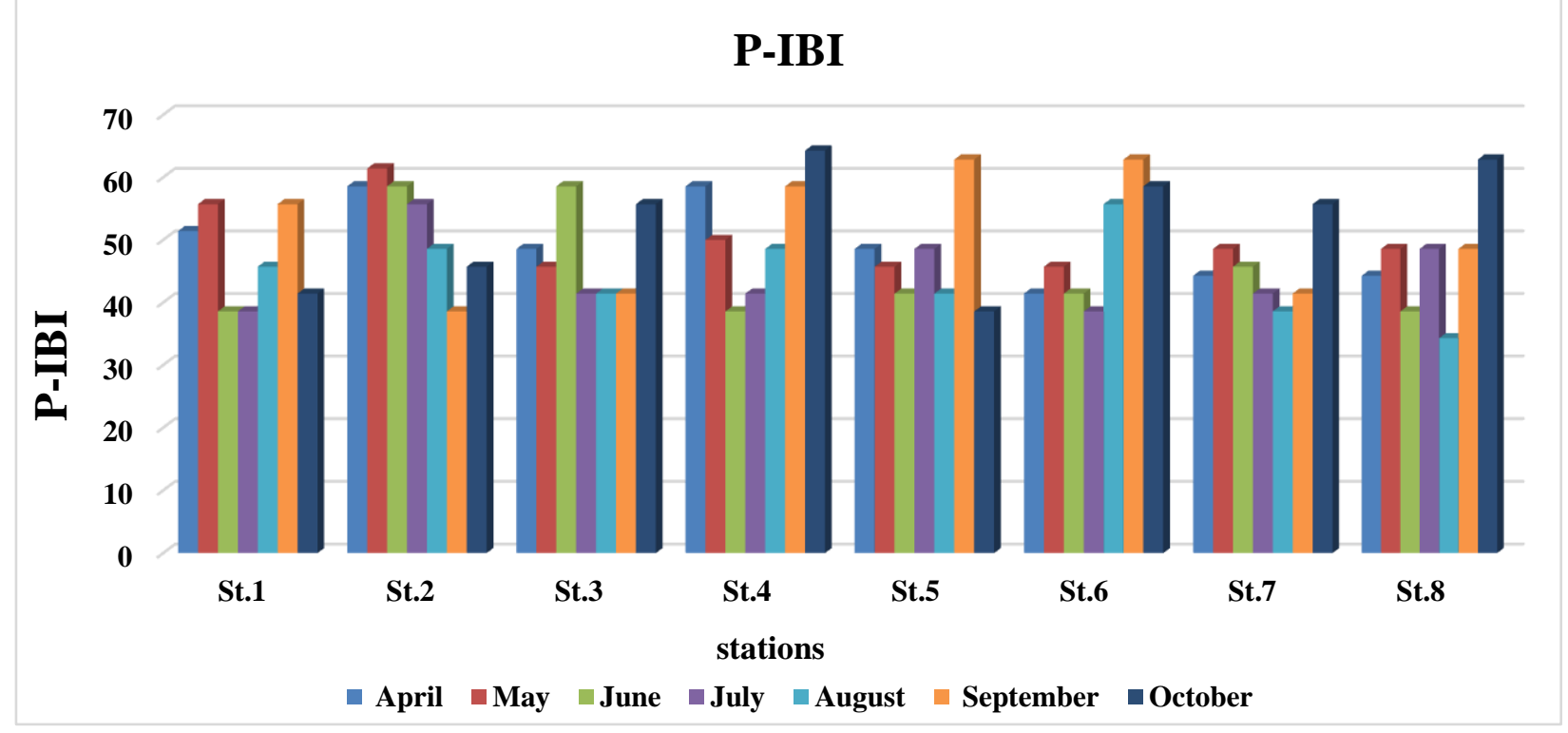

Figure 9. Monthly P-IBI scores for the studies stations.

It was found that all the studied stations, the average P-IBI values fell within the range of 45.0952.4. Therefore, water throughout the entire study area was characterized by the same "poor" quality. Thus, the evident influence of the city on the deterioration of river water quality does not have an effect. Poor water quality is probably due to the total pollution entering the Lower Don area from the upper reaches. However, a negative point of anthropogenic impact can be identified in stations 1 (above the Aksai canal), 3,4 (below the confluence of the Temernik river), 7 (5m depth after discharge). At these points, samples with P-IBI values of more than 56, characterizing water quality as "Fair", were not found in any of the observations. The negative effect on the water at station 1 may be due to the influence of the closely located Aksai city, and at stations 3, 4 it can be due to the impact of the Temernik river. The Temernik River flows through the city of Rostov-on-Don and concentrates all types of pollution at the mouth.

\section{Conclusions:}

Studies have shown that using only metrics for assessment purposes is difficult to understand, but using P-IBI gives an objective assessment and a clear picture about water quality of Don river. Water quality based on P-IBI for the Don River is spatially characterized by uniformly poor quality. Consequently, there is no enormous negative anthropogenic influence of the city Rostov on Don.
The monthly changes are the poorest in the summer and the best evaluation is in the autumn season. Using the P-IBI gives an objective assessment and a clear picture of the Don River condition, and its results are understandable to general people (nonspecialists). The usefulness of this index in the first place which appears to be an effective way to measure the levels of anthropogenic disturbance. Local continuous monitoring plans based on the selection of the most suitable and effective metrics are recommended. In Russia P-IBI has not been applied, so this study can be considered as the first study to conduct an environmental assessment of the Don River status using the phytoplankton index of biological integrity and develop scoring criteria of the Don River. P-IBI may further be used as a basic information applied on Don river and other watercourses to the south of Russia.

\section{Acknowledgments:}

We would like to thank Marina Nikolaevna Taradaiko for her help in sampling phytoplankton and Galina Genievna Chernikova for her advice in identifying microalgae species. This work is part of the laboratory experimental hydrochemistry of the Hydrochemical Institute, Rostov-on-Don, Russia.

\section{Authors' declaration:}

- Conflicts of Interest: None. 
- We hereby confirm that all the Figures and Tables in the manuscript are mine ours. Besides, the Figures and images, which are not mine ours, have been given the permission for re-publication attached with the manuscript.

- Ethical Clearance: The project was approved by the local ethical committee in Southern Federal University, Russia.

\section{References:}

1. Li TY, Li SY, Liang C, Bush RT, Xiong LH., Jiang YJ. A comparative assessment of Australia's Lower Lakes water quality under extreme drought and post-drought conditions using multivariate statistical techniques. J. Clean. Prod. 2018. 190, pp. 1-11.

2. Yearbook. Surface water quality of the Russian Federation. St. Petersburg: Gidrometeoizdat, $2017.556 \mathrm{~s}$.

3. Voulvoulis N, Arpon KD, Giakoumis T. The EU Water Framework Directive:from great expectations to problems with implementation. Sci. Total Environ. 2017. 575,358-366.

4. Bakaeva EN, Nikanorov AM, Ignatova NA, Chernikova GG. Ecological and toxicological situation of the Tsimlyansk reservoir in the modern period // All-Russian scientific conference "Water and water resources: system-forming functions in nature and the economy" (Tsimlyansk, July 23-28, 2012). Novocherkassk: SRSTU (NPI), S. 2012. 151157.

5. Monaghan KA. Four reasons to question the accuracy of a biotic index, the risk of metric bias and the scope to improve accuracy. PLoS One 2016. 11, 7e.

6. Brown ED, Williams BK. Ecological integrity assessment as a metric of biodiversity: are we measuring what we say we are? Biodivers. Conserv. 2016. 25, 1011-1035.

7. Zachary C, Johnson a, Scott G, Leibowitz b, Ryan A. Hill. Revising the index of watershed integrity national maps. 2019. 651, 2615-2630.

8. Scown MW, Flotemersch, JE, Spanbauer TL, Eason T, Garmestani A, Chaffin BC . People and water: exploring the social-ecological condition of watersheds of the United States. Elementa (Wash. D.C.) 2017. 5, 64.

9. Karr JR. " Biological integrity: along-neglected aspect of water resource management". Ecological Applications, 1991.Vol.1,No.1,pp.66-84. doi: $10.2307 / 1941848$

10. Kane DD." The Development of Planktonic Index of Biotic Integrity for Lake Erie", Ph.D. Dissertation, Ohio State University. 2004. 277p.

11. O'Brien A, Townsend K, Hale R, Sharley D, Pettigrove V. How is ecosystem health defined and measured? a critical review of freshwater and estuarine studies. Ecol. Ind. 2016. 69, 722-729. https://doi.org/10.1016/j.ecolind.2016.05.004.

12. Zhaoshi W, Kuanyi L. Index of biotic integrity based on phytoplankton and water quality index: Do they have a similar pattern on water quality assessment? A study of rivers in Lake Taihu Basin, China. 2019. Vol.658, pp.395-404.

13. Claire HD et al. A database of marine phytoplankton abundance, biomass and species composition in Australian waters. SCIENTIFIC DATA | 3:160043 | DOI: $10.1038 /$ sdata. 2016.43

14. Cai W, Xia J, Yang M, Wang W, Dou C, Zeng Z, Dong S, Sheng L. Cross-basin analysis of freshwater ecosystem health based on a zooplankton based Index of Biotic Integrity: Models and application. Ecol. Indic., 2020.vol. 114, p. 106333.

15. Souza GBG, Vianna M. Fish-based indices for assessing ecological quality and biotic integrity in transitional waters: A systematic review. Ecol. Indic., 2020. Vol 109, p 105665.

16. Lurie PM, Panov VD. Ecological and geographical problems of the south of Russia. Rostov-on-Don. Publishing house "Hephaestus". 1999. 256s.

17. Yearbook of surface water quality according to hydrobiological indicators in the territory of the North Caucasus UGKS in 1987 (Lower Don). Rostov-on-Don 1988. Ex. N. 1.

18. Sournia A. Phytoplankton manual. In "Monographs on Oceanographic Methodology 6" UNESCO, Paris. 1978. pp. 337.

19. Dedusenko-Schegoleva NT, Matvienko AM, Shkorbatov LA. Green algae. Key to Freshwater Algae of the USSR. 1959, Issue 8.

20. Germain H. Flore Des Diatomées, Diatomophycées. Société Nouvelle Des Éditions Boubée, Paris. 1981.

21. Gollerbach MM, Kosinskaya EK, Polyansky VI . Blue-green algae. Key to Freshwater Algae of the USSR. 1953, Issue 2.

22. Popova TG. Euglenae algae. Determinant of Freshwater algae of the USSR, 1955, Issue 7.

23. Prescott GW. Algae of the Western Great Lakes Area. William C. Brown Publishers, Dubuque. 1982.

24. Zabelina MM, Kiselev IA . Proshkina-Lavrenko A.I., Sheshukova V.S.. Diatoms. Key to Freshwater Algae of the USSR, 1951, Issue 4.

25. Astin LE. Developing Biological Indicators from Diverse Data: the Potomac Basin-Wild index ofBenthic Integrity (B-IPI). Ecol. Indic., 2007. 7(4): 895-908

26. Yearbook of surface water quality according to hydrobiological indicators in the territory of the North Caucasus UGKS in 1985 (Lower Don). Rostov-on-Don 1986. Ex. N. 1.

27. Yearbook of surface water quality according to hydrobiological indicators in the territory of the North Caucasus UGKS in 1986 (Lower Don). Rostov-on-Don 1987. Ex. N. 1.

28. U.S. Environmental Protection Agency. Mid-Atlantic Integrated Assessment (MAIA) State of the Flowing Waters Report. EPA/620/R-06/001, U.S. Environmental Protection Agency, Office of Research and Development Washington, 2006. DC 20460.

29. Maulood BK, Alobaidy AHMJ, Alsaboonchi A, Abid HS, Alobaidy GS. PhytoplanktonIndex of Biological Integrity (P-IBI) in Several Marshes, Southern IRAQ. J. of Environ. Protection, 2011. 2(4): 387-394. 
30. McCormick FH, Hughes RH, Kaufmann PR, Peck DV, Stoddard JL, Herlihy AT. Development index of biotic integrity for the Mid-Atlantic Highlands Region. Trans. Am. Fish. Soc.. 2001. Vol.130, pp. 857-877.

31. Song WW, Xu Q, Fu XQ, Zhang P, Pang Y, Song DH. Research on the relationship between water diversion and water quality of Xuanwu Lake, China. Int. J. Environ. Res. Pub. He. 2018. 15.

32. Hassan FM.1993. Alimnological study on Hilla river. Al-Mustansiriya J. Sci, 8,pp.22-30.

33. Wu P, Qin BQ, Yu G, Deng JM, Zhou J. Effects of nutrient on algae biomass during summer and winter in inflow rivers of Taihu Basin, China. Water Environ. Res. 2016. 88,665-672.

34. Katsiapi M, Mousta-Gouni M, Sommer U. Assessing ecological water quality of freshwaters: PhyCol- a new phytoplankton community Index, Ecol Inform., 2016 .Vol. 31, pp. 22-29.

35. Deppeler SL, Davidson AT. Southern Ocean phytoplankton in a changing climate. Front Mar Sci. 2017.

4:40. https://doi.org/10.3389/fmars.2017.00040

36. GD 52.24.309. Organization and conduct of regime monitoring of the condition and pollution of surface land waters/. Rostov-on-Don: Roshydromet, Hydrochemical Institute. 2016. 99 p.

\section{أستخدام مؤشر التكامل البيولوجي للهائمات التباتية في تقيم جودة مياه نهر الاون}

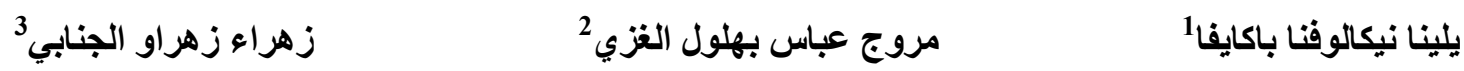

1قسم معهد الكيمياء المائية، رستوف على الدون، روسيا، جامعة الجنوب الفدر الية، معهد علم الارض، معهذ مشاكل المياه الاكاديمية الروسية

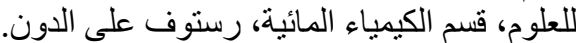

2جامعة الجنوب الفدر الية، أكاديمية الاحية العياء والتكنولوجيا الحيوية رستوف على الديون، روسيا، قسم الاحياء كلية العلوم، جامعة ذي قار،

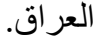

$$
\text { 3ركز بحوث البيئة، الجامعة التكنولوجيا ،بغداد، العراق. }
$$

نم تطبيق مؤشر الهائمات النباتية للتكامل الاحيائي ( P-IBI) في جميع أنحاء مدينة روستوف على دون (روسيا) في 8 محطات على نهر

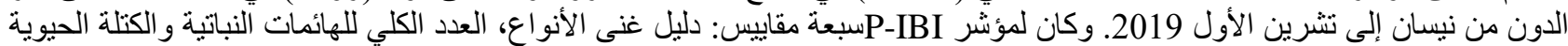

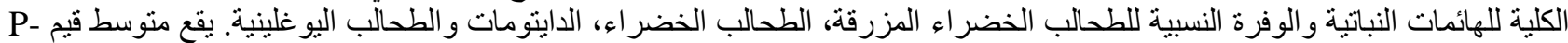
IBI في حدود (52.4-45.9). لللك، تميزت المياه في جميع أنحاء منطقة الدراسة بنوعية "سيئة" على حد سواء. أثر إلى الثى الأثر السلبي

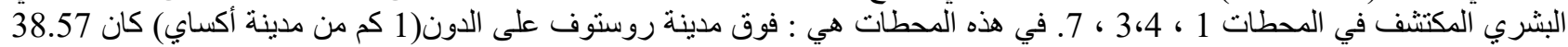

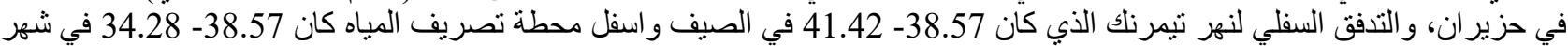

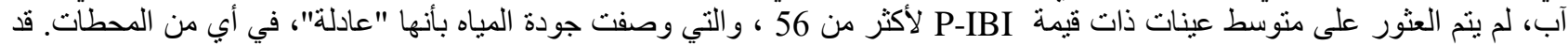

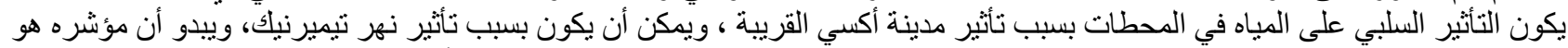

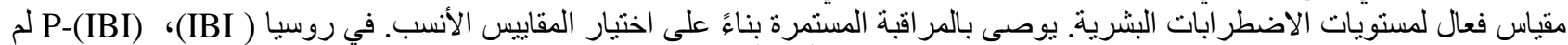

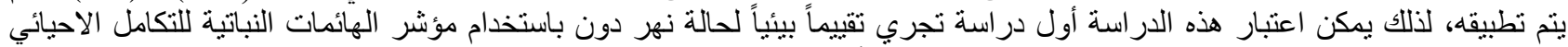

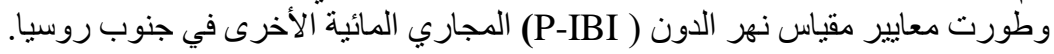

الكلمات المفتاحية: التقييم، P-IBI, ،الهائمات النباتية، نوعية المياه، نهر الدون، مدينة رستوف على الدون، روسيا. 